\title{
PENGARUH MOTIVASI BELAJAR DAN GAYA BELAJAR TERHADAP PRESTASI BELAJAR EKONOMI SISWA SMA NEGERI DI KOTA TUBAN
}

\author{
Joenita Darmawati*
}

\begin{abstract}
This study aims to determine 1) the influence of motivation on learning achievement, 2) the influence of learning style on learning achievement, and 3) the influence of motivation and learning styles on learning achievement. The populations were 379 senior high school students of grade XI in Tuban. Samples were taken by employing simple random sampling technique yielding in 195 students. Data were collected by using questionnaires. Data was analyzed by using the multiple linear regression analysis. Finding indicates that the partial test ( $\mathrm{t}$ test) concluded the significant effect of motivation on students' achievement and the significant effect of learning styles on academic achievement. Based on F test, it was concluded that both motivation and learning styles simultaneously affect students' achievement. Consequently, students are suggested to know more about their own learning styles to optimize their learning achievement. Teachers are also advised to design their instruction in such a way that it accommodates all the learning styles.

Key words: motivation, learning style, and academic achievement
\end{abstract}

\section{PENDAHULUAN}

$\mathrm{P}$ endidikan adalah suatu usaha atau kegiatan yang dijalankan dengan sengaja,teratur dan berencana dengan maksud mengubah atau mengembangkan perilaku yang diinginkan. Sekolah sebagai lembaga pendidikan formal merupakan sarana dalam rangka pencapaian tujuan pendidikan, seperti yang tertuang dalam Undang-Undang No.20 Tahun 2003 tentang tujuan Pendidikan Nasional Bab II Pasal 3. Dengan adanya undang-undang tersebut, maka salah satu tugas pokok sekolah adalah menyiapkan siswa agar dapat mencapai perkembangannya secara optimal. Seorang siswa dikatakan telah mencapai perkembanganya secara optimal apabila siswa dapat memperoleh pendidikan dan pretasi belajar yang sesuai dengan bakat, kemampuan dan minat yang dimilikinya.

Upaya menciptakan manusia yang berkualitas dan berprestasi tinggi, maka siswa harus memiliki prestasi belajar yang baik. Prestasi belajar merupakan tolak ukur yang telah dicapai siswa setelah melakukan perbuatan belajar selama waktu yang telah ditentukan bersama. Fenomena yang terjadi di SMA Kota Tuban prestasi belajar yang diraih siswa mata pelajaran ekonomi kelas XI rerata 72,34 masih rendah dibawah Kriteria Ketuntatasan Minimum (KKM) yang ditetapkan masing-masing sekolah.

Berdasarkan beberapa penelitian terdahulu, terdapat beberapa faktor yang dapat mempengaruhi prestasi belajar siswa diantaranya motivasi, dan gaya belajar. Kedua fak-

*) Guru SMA Negeri 1 Widang Tuban 
tor ini menjadi penting untuk diteliti kembali karena dalam penelitian terdahulu, terbukti kedua faktor tersebut signifikan mempengaruhi prestasi belajar. Berdasarkan kondisi yang berbeda dengan penelitian terdahulu maka dilakukan penelitian di SMA Negeri di Kota Tuban untuk menjawab permasalahan tentang adakah pengaruh motivasi, gaya belajar terhadap prestasi belajar siswa.

Prestasi belajar adalah sesuatu perubahan yang terjadi pada diri siswa setelah dilakukannya proses belajar. Senada dengan pernyataan Syaodih (2009: 124) prestasi belajar merupakan segala perilaku yang dimiliki siswa sebagai akibat dari proses belajar yang ditempuhnya, meliputi semua akibat dari proses belajar yang berlangsung di sekolah atau di luar sekolah yang bersifat kognitif, afektif, maupun psikomotorik baik yang di sengaja ataupun yang tidak disengaja. Sumadi Suryabrata (2002:225) mengatakan prestasi belajar sebagai nilai yang merupakan bentuk perumusan akhir yang diberikan oleh guru terkait dengan kemajuan atau prestasi belajar siswa selama waktu tertentu.

Tinggi rendahnya hasil belajar tersebut sering dikatakan dengan istilah prestasi belajar. Hal ini sesuai yang diungkapkan Muhibbin Syah (2010:100) bahwa Prestasi belajar digunakan untuk menentukan taraf keberhasilan sebuah proses belajar mengajar atau untuk menentukan taraf keberhasilan sebuah program pengajaran . Dari pernyataan diatas dapat dilihat bahwa prestasi belajar merupakan pencapaian yang telah diraih siswa setelah proses belajar dilakukan, dimana keberhasilan siswa dalam meraih prestasi belajar dipengaruhi beberapa faktor.

Salah satu faktor yang berpengaruh terhadap prestasi belajar siswa yaitu motivasi belajar. Menurut Sardiman (2007:73) motivasi adalah daya upaya yang mendorong seseorang untuk melakukan sesuatu atau daya penggerak dari subyek untuk melakukan suatu perbuatan dalam suatu tujuan. Lebih lanjut menurut Dimyati (2006:80) motivasi belajar dipandang sebagai dorongan mental yang menggerakkan dan mengarahkan perilaku manusia, termasuk perilaku belajar. Dalam motivasi terkandung adanya keinginan yang mengaktifkan, menggerakkan, menyalurkan, dan mengarahkan sikap dan perilaku individu belajar. Motivasi belajar juga dapat diartikan sebagai perubahan energy dalam diri seseorang itu berbentuk aktivitas nyata berupa kegiatan fisik, Mc Donald (Djamarah,2002:114). Dari pengertian yang dikemukakan Mc. Donald mengandung tiga elemen penting yaitu :

1. Bahwa motivasi itu mengawali terjadinya perubahan energi pada diri setiap individu manusia.

2. Motivasi ditandai dengan munculnya, rasa/"feeling", afeksi seseorang. Dalam hal ini motivasi relevan dengan persoalan-persoalan kejiwaan, afeksi dan emosi yang dapat menentukan tingkah-laku manusia.

3. Motivasi akan dirangsang karena adanya tujuan. Jadi motivasi dalam hal ini sebenarnya merupakan respon dari suatu aksi, yakni tujuan menurut Sardiman (2005:74)

Dalam psikologi motivasi diartikan suatu yang terdapat dalam diri seseorang yang dapat mempengaruhi tingkah lakunya dalam melakukan kegiatan. Sedangkan menurut Ahmadi dan Supriyono (2004:83) motivasi sebagai suatu inner (batin) berfungsi menimbulkan, mendasari, dan mengarahkan perbuatan belajar.

Sedangkan menurut Uno (2006:23) motivasi dan belajar merupakan dua hal yang saling mempengaruhi. Belajar adalah perubahan tingkah laku secara relative permanen dan secara potensial terjadi sebagai hasil dari praktek atau penguatan yang dilandasi tujuan untuk mencapai tujuan tertentu. 
Indikator motivasi belajar dapat diklasifikasikan sebagai berikut:

1. adanya hasrat dan keinginan berhasil

2. adanya dorongan dan kebutuhan belajar

3. adanya harapan dan cita-cita masa depan

4. adanya penghargaan dalam belajar

5. adanya kegiatan yang menarik dalam belajar

6. adanya lingkungan belajar yang kondusif.

Dari berbagai definisi yang dikemukakan oleh para ahli di atas, dapat disimpulkan bahwa motivasi adalah sesuatu yang komples, karena motivasi dapat menyebabkan terjadinya perubahan energy dalam diri individu untuk melakukan sesuatu yang didorong karena ada tujuan, kebutuhan, atau keinginan. Sedangkan secara sederhana motivasi dapat didefinisikan sebagai dorongan, baik yang berasal dari dalam diri (internal) ataupun dari luar (eksternal) individu untuk mencapai tujuan tertentu.

Dalam proses belajar, motivasi sangat diperlukan sebab yang tidak mempunyai motivasi dalam belajar, tidak akan mungkin melakukan aktivitas belajar.

Ciri-ciri motivasi belajar menurut Sardiman (2007:83) motivasi yang ada pada diri setiap orang itu memiliki ciri-ciri. Adapun ciri-ciri yang diungkapkan sebagai berikut :

a. Tekun menghadapi tugas (dapat bekerja terus-menerus dalam waktu yang lama,tidak pernah berhenti sebelem selesai).

b. Ulet menghadapi kesulitan (tidak lekas putus asa).tidak memerlukan dorongan dari luar untuk berprestasi sebaik mungkin (tidak cepat puas dengan prestasi yang telah dicapainya).

c. Menunjukkan minat terhadap bermacam-macam masalah .

d. Lebih senang bekerja mandiri.

e. Cepat bosan pada tugas-tugas yang rutin (hal-hal yang bersifat mekanis,berulangulang begitu sehingga kurang kreatif).

f. Dapat mempertahankan pendapatnya

g. Tidak mudah melepaskan hal yang diyakini itu.

h. Senang mencari dan memecahkan masalah soal-soal.

Apabila siswa memiliki ciri-ciri seperti di atas, maka siswa itu akan memiliki motivasi yang cukup kuat. Dalam kegiatan belajar mengajar akan berhasil baik, kalau siswa tekun mengerjakan tugas, ulet dalam memecahkan masalah dan hambatan secara mandiri. Siswa yang telah termotivasi maka akan memiliki keinginan dan harapan untuk berhasil dan jika mengalami kegagalan maka siswa tersebut akan berusaha sekuat tenaga untuk dapat mencapai keberhasilannya yang ditunjukkan dalam prestasi belajar. Dengan usaha yang tekun dan didasari motivasi yang kuat maka akan menghasilkan prestasi belajar yang baik.

Faktor lain yang berpengaruh terhadap prestasi belajar yaitu gaya belajar siswa. Menurut Nasution (2003:94) gaya belajar adalah cara yang dilakukan murid dalam menangkap suatu informasi dengan cara mengingat, berpikir dan memecahkan masalah, dimana berkaitan dengan pribadi seseorang yang dipengaruhi oleh pendidikan dan riwayat perkembangannya. Joko Susilo (2006:94) mengatakan gaya belajar adalah cara yang cenderung dipilih seseorang untuk menerima informasi dari lingkungan dan memproses informasi tersebut.

Berdasarkan pengertian diatas, dapat disimpulkan bahwa gaya belajar adalah cara seseorang dalam menyerap informasi (pelajaran), mengingat informasi tersebut dan cara 
berpikir dalam memecahkan masalah yang di didasarkan kepribadian siswa tersebut. Menurut DePorter \& Hernacki (2001:112) ada tiga macam gaya belajar yaitu:

1. Gaya belajar visual

Gaya belajar visual adalah gaya belajar cenderung lebih dominan dalam penglihatannya dibanding dengan pendengaran dan gerakan-gerakan. Gaya belajar visual cenderung lebih khusus belajar melihat pada focus telaahannya.

Karateristik gaya belajar Visual adalah :

a. Rapi dan teratur

b. Berbicara dengan cepat

c. Perencanaan dan pengatur jangka panjang yang lain

d. Teliti dan mendetail

e. Mementingkan penampilan dan tulisan

f. Pengeja yang baik dan dapat melihat kata-kata yang sebenarnya dalam pikiran mereka.

g. Mengingat apa yang dilihat,daripada yang didengar

h. Mengingat dengan asosiasi visual

i. Biasanya tidak tertanggu oleh keributan

j. Mengalami kesulitan mengingat instruksi verbal

k. Pembaca cepat dan tekun

1. Mencoret-coret tanpa arti ketika menerima telepon atau selama mengikuti pelajaran

m. Sering lupa menyampaikan pesan verbal kepada orang lain

n. Menjawab pertanyaan dengan singkat

o. Lebih suka berdemonstrasi daripada pidato

p. Lebih suka seni lukis,drama,tarian dan sejenisnya daripada music

q. Sering kali tahu apa yang harus dilakukan tetapi tidak pandai memilih kata-kata

Karateristik gaya belajar visual diatas, yang memegang peranan penting yaitu mata/ penglihatan (visual), dalam hal ini penggunaan metode pengajaran guru lebih dititikberatkan pada peragaan atau media,ajak mereka ke objek-objek berkaitan dengan pelajaran tersebut, atau dengan cara menunjukkan alat peraga langsung pada siswa atau menggambarkannya di papan tulis. Gaya belajar visual harus melihat bahasa tubuh dan ekspresi muka gurunya supaya mengerti materi pelajaran. Mereka cenderung untuk duduk di depan agar dapat melihat dengan jelas. Mereka berpikir menggunakan gambar-gambar di otak mereka dan belajar lebih cepat dengan menggunakan tampilan-tampilan visual, seperti diagram,buku pelajaran bergambar, video dan lebih suka mencatat sampai detildetilnya dalam mendapatkan informasi.

2. Gaya belajar auditorial

Gaya belajar auditorial adalah gaya belajar yang cenderung melalui suara dalam proses pembelajaran.

Karateristik gaya belajar auditorial adalah :

a. Sering berbicara dengan dirinya sendiri saat belajar

b. Mudah terganggu oleh keributan

c. Menggerakkan bibir dan mengucapkan tulisan di buku ketika membaca

d. Senang mendengarkan dan membaca dengan suara keras

e. Mampu mengulangi dan menirukan nada dan suara

f. Kesulitan dalam menulis tetapi pandai dalam bercerita 
g. Berbicara dalam irama yang terpola

h. Biasanya merupakan pembicara yang fasih

i. Belajar dengan mendengarkan dan mengingat apa yang didiskusikan

j. Suka berbicara,berdiskusi,dan menjelaskan sesuatu dengan panjang lebar

k. Kesulitan dalam pekerjaan yang melibatkan visualisasi

1. Lebih pandai mengeja dengan keras daripada menuliskannya

m. Lebih suka gurauan lisan daripada cerita lucu dari komik

Karateristik gaya belajar tersebut dapat disimpulkan, siswa yang mempunyai gaya belajar auditorial dapat belajar lebih cepat dengan menggunakan diskusi verbal dan mendengarkan penjelasan guru. Gaya belajar auditorial dapat mencerna makna penyampaian melalui suara, kecepatan berbicara dan hal-hal lain auditorial mendengakannya. Siswa seperti ini biasanya dapat menghafal lebih cepat dengan membaca dengan bersuara serta memlalui media seperti kaset, radio dan lain-lain.

3. Gaya belajar kinestetik

Gaya belajar kinestetik adalah gaya belajar dengan melakukan segala sesuatu secara langsung melalui gerak dan sentuhan.

Karateristik gaya belajar kinestetik adalah :

a. Berbicara dengan perlahan

b. Menanggapai perhatian fisik

c. Menyentuh orang untuk menarik perhatian mereka

d. Berdiri dekat ketika berbicara dengan orang

e. Berorientasi pada fisik dan senang bergerak

f. Belajar memaluli praktik

g. Menghafal dengan cara berjalan dan melihat-lihat

h. Menggunakan jari sebagai penunjuk ketika membaca

i. Banyak menggunakan isyarat tubuh

j. Tidak dapat duduk dalam waktu lama

k. Menggunakan kata-kata yang mengandung arti

1. Membaca dengan menyertakan gerakan fisik sesuai dengan isi cerita

m. Kemungkinan tulisannya jelek

n. Selalu ingin mempratekkan segala sesuatu

o. Suka permainan yang menyibukkan

Siswa yang mempunyai gaya belajar kinestetik belajar melalui bergerak,menyentuh, dan melakukan. Siswa seperti ini sulit untuk duduk diam berjam-jam karena keinginan mereka untuk beraktifitas dan bereksplorasi sangatlah kuat. Sehingga gaya belajar seprti ini, proses belajarnya melalui gerak dan sentuhan .

Ketiga jenis gaya belajar tersebut memiliki ciri-ciri dominan dalam melakukan suatu kegiatan. Begitu pula dengan gaya belajar siswa,terlihat adanya ciri-ciri dominan dalam suatu proses kegiatan pembelajaran, sehingga dapat mencapai hasil maksimal.

Menurut Uno (2005:180) Fenomena yang ada bahwa tidak semua orang punya gaya belajar yang sama . Termasuk apabila mereka bersekolah di sekolah yang sama atau bahkan duduk di kelas yang sama. Kemampuan seseorang untuk memahami dan menyerap pelajarn sudah pasti berbeda tingkatannya. Ada yang cepat, sedang, dan ada pula yang sangat lambat. Apapun cara yang dipilih, perbedaan gaya belajar itu menunjukan cara tercepat dan terbaik bagi setiap indivivu untuk bisa menyerap sebuah informasi dari luar dirinya. 
Kemampuan seseorang untuk mengetahui sendiri gaya belajarnya dan gaya belajar orang lain dalam lingkungannya akan meningkatkan efektifitas dalam belajar disebutkan oleh Honey dan Mumford (Ghufron 2012:138) tentang pentingnya setiap indivivu mengetahui gaya belajar masing-masing adalah :

1. Meningkatkan kesadaran kita tentang aktivitas belajar mana yang cocok atau tidak cocok dengan gaya belajar kita.

2. Membantu menentukan pilihan yang tepat dari sekian banyak aktivitas.

3. Individu dengan kemapuan belajar efektif yang kurang, dapat melakukan improvisasi.

4. Membantu individu untuk merencanakan tujuan dari belajarnya, serta menganlisa tingkat keberhasilan seseorang.

Temuan penelitian tentang prestasi belajar diantaranya: Mulyono dkk (2007) menyatakan bahwa mayoritas mahasiswa memiliki modalitas Visual. Pelatihan gaya belajar berpengaruh terhadap kenaikan Indeks Prestasi, Lain halnya dengan Kertamuda (2008) menyatakan bahwa terdapat perbedaan yang signifikan pengaruh motivasi belajar terhadap prestasi belajar pada siswa yang tidak tinggal di pesantren dan siswa yang tinggal di pesantern. Motivasi belajar dan prestasi belajar pada siswa yang tidak tinggal di pesantren lebih tinggi disbanding pada siswa yang tinggal di pesantren, Sawitri dan Pujiningsih (2009) menyatakan bahwa: tidak terdapat perbedaan preferensi gaya belajar diantara mahasiswa, dan tidak terdapat pengaruh preferensi gaya belajar terhadap hasil belajar mahasiswa jurusan akuntansi, Arini (2009) menyatakan ada pengaruh secara signifikan dari tingkat intelegensi dan motivasi belajar baik secara parsial maupun bersama terhadap prestasi akademik, Tanta (2010) menyatakan bahwa: gaya belajar mahasiswa Program Studi Pendidikan Biologi semester 1 pembelajaran 2009/2010 adalah gaya belajar visual, dan gaya belajar secara signifikan berpengaruh terhadap hasil belajar mahasiswa Program Studi Pendidikan Biologi mata kuliah Biologi Umum, Gullam dan Lisa (2011) menyatakan bahwa motivasi belajar siswa memiliki pengaruh yang signifikan terhadap prestasi belajar IPA dan menunjukkan interprestasi tingkat reliabilitas tinggi besarnya pengaruh motivasi, Sukirman (2011) menyatakan bahwa terdapat hubungan positif (berperan) dan signifikan antara bimbingan guru dengan prestasi belajar, Abidin (2011) menyatakan ada pengaruh yang signifikan antara prestasi akademik dengan gaya belajar dengan menunjukkan prestasi yang tinggi, rendah, dan sedang memiliki pola preferensi yang sama belajar disemua gaya belajar, Englander,dkk (2011) menyatakan ada pengaruh yang signifikan antara gaya belajar denga prestasi belajar, Indarto (2012) mengatakan bahwa terdapat pengaruh yang positif dan signifikan antara gaya belajar siswa dengan prestasi belajar Praktik Instalasi Listrik. Hal ini berarti bahwa semakin baik gaya belajar siswa, maka semakin baik pula prestasi belajar yang dicapai siswa.

Berdasarkan kajian pustaka diatas,peneliti merumuskan hipotesis sebagai berikut :

1. Diduga motivasi belajar berpengaruh signifikan terhadap prestasi belajar

2. Diduga gaya belajar berpengaruh signifikan terhadap prestasi belajar

3. Diduga motivasi, dan gaya belajar secara bersama-sama berpengaruh signifikan terhadap prestasi belajar.

\section{METODE PENELITIAN}

Pendekatan dalam penelitian ini adalah pendekatan kuantitatif. Penelitian ini diran- 
cang dengan menggunakan penelitian asosiatif. Variabel yang digunakan pada penelitian ini yaitu prestasi belajar (Y), serta motivasi belajar (X1) dan gaya belajar (X2).

Populasi dalam penelitian ini adalah siswa kelas XI IPS SMA Negeri di Kota Tuban yaitu SMA Negeri 1, SMA Negeri 2, SMA Negeri 3, SMA Negeri 4, dan SMA Negeri 5 sebanyak 379 siswa. Sedangkan sampel penelitian ini yang diambil secara simple random sampling yaitu secara acak sebanyak 195 siswa. Data dikumpulkan melalui kuesioner, dan dokumentasi. Kuesioner disusun berdasarkan variable penelitian dan indicator penelitian dengan skala pengukuran instrument menggunakan skala likert. Teknik analisis menggunakan analisis uji statistik yaitu uji $\mathrm{F}$ dan Uji t. Uji F digunakan untuk menguji signifikansi variable motivasi, gaya belajar terhadap prestasi belajar, Uji t digunakan untuk menguji signifikansi pengaruh motivasi belajar terhadap prestasi belajarpengaruh gaya belajar terhadap prestasi belajar.

\section{HASIL PENELITIAN DAN PEMBAHASAN}

\section{Hasil Penelitian}

Uji asumsi klasik meliputi uji linieritas, normalitas, multikolinearitas, dan Heteroskedastisitas.

1. Uji Linieritas dapat dilihat dari nilai $F$ (Deviation from linearity). Nilai $F$ yang dihasilkan X1 terhadap Y sebesar 0,667 dengan nilai signifikan lebih dari 5\% yaitu sebesar 0,911. Karena tingkat signifikan yang dihasilkan melebihi 5\% maka hubungan antara mptivasi belajar (X1) dengan prestasi belajar (Y) adalah linier. Sedangkan uji linieritas untuk X2 dengan Y nilai F yang dihasilkan sebesar 0,996 dengan nilai signifikan lebih dari 5\% yaitu sebesar 0,487. Karena tingkat signifikan yang dihasilkan melebihi 5\% maka hubungan antara gaya belajar (X2) dengan prestasi belajar (Y) adalah linier.

2. Uji Normalitas menggunakan Uji Kolmogorov Smirnov dengan bantuan SPSS 17.0 for Windows dihasilkan Asymp. Sig $>0,05$. Tingkat signifikan yang dihasilkan lebih dari 5\%, dengan demikian asumsi normalitas data terpenuhi.

3. Uji Multikolinearitas, dilakukan dengan bantuan SPSS 17.0 for Windows ditunjukkan oleh tabel coefficient dengan mengamati kolom tolerance dan kolom VIF. Didapatkan nilai tolerance kedua variable $>0,1$ dan nilai VIF kedua variable $<10$. Dengan demikian tidak ada multikolinearitas antara variable bebas dalam model regresi.

4. Uji Heteroskedastisitas menggunakan uji Rank Spearman didapat signifikansi untuk X1 $=0,781>0,05$, untuk X2 $=0,419>0,05$. Hal ini dapat dikatakan bahwa antara variabel bebas dengan residual tidak terjadi heteroskedastisitas.

Model regresi yang yang diperoleh berdasarkan hasil penelitian, dapat dituliskan dalam bentuk persamaan regresi adalah sebagai berikut: $\mathrm{Y}=10,475+10,189 \mathrm{X} 1+6,496$ $\mathrm{X} 2$. Dari persamaan diatas, kedua variable bebas memiliki koefisien regresi dengan arah positif. Hal ini berarti bahwa semakin tinggi motivasi dan gaya belajar maka prestasi belajar akan naik. Hasil Uji F berdasarkan uji ANOVA atau uji statistik F, model menunjukkan nilai Fhitung $=37,613$ dengan nilai signifikansi $p=0,000$ lebih kecil dari 5\%. Hal ini berarti bahwa motivasi belajar dan gaya belajar secara signifikan mempengaruhi prestasi belajar.

Besarnya pengaruh motivasi belajar dan gaya belajar secara simultan terhadap 
prestasi belajar dapat dilihat dari koefisien determinasi (R-square). Berdasarkan hasil uji F dihasilkan koefisien korelasi sebesar 0,531 berarti 28,2\% prestasi belajar dipengaruhi oleh motivasi belajar dan gaya belajar. Sedangkan $71,8 \%$ dipengaruhi oleh variable lain yaitu diantaranya intelegensi, lingkungan belajar dan sarana prasarana.

Selanjutnya Uji parsial menunjukkan semua variable pengaruhnya signifikan. Uji parsial untuk variable motivasi belajar (X1) nilai t hitung sebesar 6,040 dengan tingkat signifikansi sebesar 5\% yaitu 0,000, variable gaya belajar (X2) nilai t hitung 4,300 dengan tingkat signifikansi 5\% yaitu 0,000. Dengan demikian variable motivasi (x1) dan gaya belajar (X2) signifikan pengaruhnya terhadap prestasi belajar.

Besarnya pengaruh motivasi dan gaya belajar terhadap prestasi belajar siswa dapat dilihat dari nilai r2parsial pada variabel motivasi belajar (X1) sebesar 0,160 menunjukkan bahwa motivasi belajar (X1) secara parsial berpengaruh terhadap prestasi belajar (Y) sebesar 16\%. Sedangkan nilai r2parsial pada variabel gaya belajar (X2) sebesar 0,088 menunjukkan bahwa gaya belajar (X2) secara parsial berpengaruh terhadap prestasi belajar (Y) sebesar 8,8\%.

Berdasarkan hasil pengolah data maka dapat disimpulkan hasil uji hipotesis pada gambar berikut :

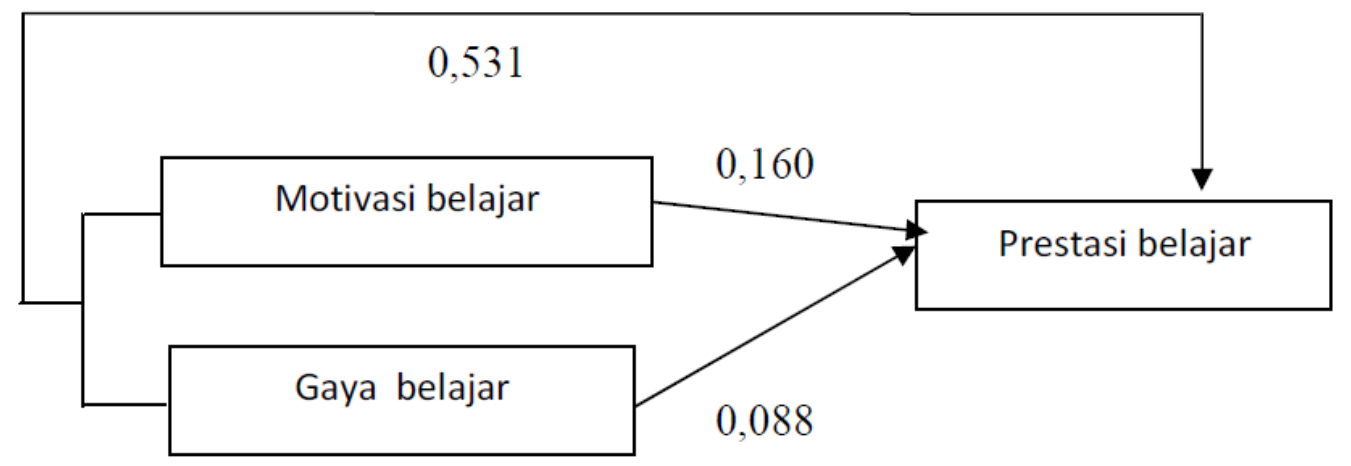

Sumber : Data primer yang diolah, 2013

\section{Gambar 1 : Hasil Uji Hipotesis}

\section{Pembahasan}

1. Pengaruh motivasi dan gaya belajar terhadap prestasi belajar siswa

Hasil penelitian menunjukkan bahwa secara simultan motivasi dan gaya belajar menunjukkan bahwa ada pengaruh secara signifikan terhadap prestasi belajar. Implikasi dari temuan tersebut adalah semakin tinggi motivasi dan gaya belajar maka semakin tinggi prestasi belajar. Sebaliknya semakin rendah motivasi dan gaya belajar maka semakin rendah prestasi belajar. Hal ini sesuai dengan penelitian-penelitian sebelumnya yang dilakukan oleh Indarto (2012). Prestasi belajar siswa kelas XI - IPS SMA Negeri di Kota Tuban berdasarkan tabulasi jawaban responden sebesar $61,03 \%$ ini termasuk cukup bagus. Artinya motivasi belajar siswa di tingkat SMA Negeri di Kota Tuban memiliki hasrat dan keinginan berhasil, harapan dan cita-cita masa depan, dorongan dan kebutuhan belajar, penghargaan dalam belajar, dan lingkungan belajar yang kondusif. Sedangkan gaya belajar yang mereka gunakan dalam pembelajaran ekonomi adalah gaya belajar visual. Karakter siswa dengan gaya belajar visual cenderung lebih cepat menyerap informasi dengan melihat bagaimana guru menerangkan didepan kelas baik dengan alat bantu, tu- 
lisan, data maupun gambar.

Hal ini seperti penelitian terdahulu yang dilakukan oleh Kertamuda (2008) tentang pengaruh motivasi terhadap prestasi belajar, penelitian oleh Prastiti (2009) tentang preferensi gaya belajar berpengaruh terhadap prestasi belajar siswa, dan penelitian oleh Indarto(2012) yang mengatakan gaya belajar dan motivasi berprestasi berpengaruh terhadap prestasi belajar. Prestasi belajar siswa dapat dipengaruhi oleh banyak faktor. Selain dari faktor internal siswa seperti kondisi fisik, bakat, dan minat, faktor eksternal juga mempengaruhi prestasi belajar siswa seperti perhatian orang tua, metode mengajar, sarana prasarana, lingkungan belajar, serta teman bergaul. Hasil penelitian ini mendukung hasil penelitian terdahulu dari Sukirman (2011).

Menurut Sukirman, peran bimbingan guru dan motivasi belajar dapat meningkatkan prestasi belajar siswa. Hal ini berarti bimbingan guru berperan penting dapat lebih memotivasi siswa dalam belajar dan meningkatkan prestasi belajar.

2. Pengaruh motivasi belajar terhadap prestasi belajar.

Hasil penelitian menunjukkan bahwa secara parsial motivasi belajar berpengaruh signifikan terhadap prestasi belajar siswa SMA di Kota Tuban. Implikasi dari penelitian ini adalah semakin tinggi motivasi belajar maka akan dapat meningkatkan prestasi belajar siswa.

Temuan tersebut didukung dari data responden tentang motivasi belajar siswa SMA di Kota Tuban, berdasarkan tabulasi jawaban responden sebesar 83,41\% memiliki motivasi yang cukup tinggi. Hal ini berarti siswa SMA di Kota Tuban dalam proses pembelajaran memiliki hasrat dan kinginan yang kuat untuk belajar, dorongan dan kesadaran akan kebutuhan belajar, harapan dan cita-cita masa depan, serta didukung dengan lingkungan belajar yang kondusif. Hasil penelitian ini sependapat dengan Hamdu dan Lisa (2011).

Menurut Hamdu dan Lisa mengatakan bahwa motivasi belajar berpengaruh terhadap prestasi belajar IPA di Sekolah Dasar. Hal ini berarti motivasi mempunyai peran yang sangat penting dalam pembelajaran baik itu di jenjang Sekolah Dasar sampai jenjang Sekolah Menengah Atas, siswa memiliki motivasi dalam belajar, maka prestasi belajarnya pun akan baik. Sebaliknya jika siswa memiliki kebiasaan yang buruk dalam belajar, maka prestasi belajarnya pun akan rendah.

Berdasarkan hasil tabulasi jawaban pada masing-masing motivasi belajar dapat disimpulkan bahwa nilai tertinggi terdapat penghargaan dalam belajar yang menyatakan bahwa siswa akan memiliki motivasi yang tinggi jika dalam belajar siswa diberikan reward atau penghargaan. Peran guru dalam proses pembelajaran harus lebih memperhatikan siswa. Guru dalam memberikan reward seperti memberikan pujian, angka, dan hadiah . Sedangkan nilai terendah jawaban pada tabulasi motivasi belajar terdapat dorongan dan kebutuhan belajar yaitu siswa dalam belajar dorongan untuk belajar kurang, ini disebabkkan siswa dalam belajar menganggap bahwa belajar itu hanya sebagai kewajiban bukan sebagai kebutuhan. Sehingga siswa belajar hanya dalam waktu-waktu tertentu saja seperti ulangan harian ulangan tengah semester dengan demikian belajar siswa tidak dapat maksimal.

Secara teori seperti yang dikemukakan oleh Djamarah (2002:41) mengatakan bahwa kesalahan dalam memberikan motivasi akan berakibat merugikan prestasi belajar siswa. Hal ini berarti siswa harus memiliki motivasi belajar yang tinggi untuk dapat meningkatkan presatasi belajar. 


\section{Pengaruh gaya belajar terhadap prestasi belajar siswa}

Hasil penelitian menunjukkan bahwa secara parsial gaya belajar berpengaruh signifikan terhadap prestasi belajar siswa SMA di Kota Tuban. Implikasi dari penelitian ini adalah semakin baik gaya belajar maka akan dapat meningkatkan prestasi belajar siswa.

Hasil penelitian diketahui bahwa siswa SMA Negeri di Kota Tuban yang memiliki gaya belajar visual $72,8 \%$, gaya belajar auditorial $8,2 \%$, dan gaya belajar kinestetik $19 \%$. Dengan demikian untuk matapelajaran ekonomi siswa SMA Negeri di Kota Tuban gaya belajar mereka cenderung menggunakan gaya belajar Visual. Guru matapelajaran ekonomi dalam menyampaikan materi maka strategis belajar yang dipakai dengan cara gambar, grafik, dengan menggunakan multimedia (video dan komputer) sehingga siswa dapat dengan mudah menyerap informasi yang diberikan oleh guru.

Pemakaian gaya belajar oleh individu sebenarnya merupakan sarana untuk memfasilitasi agar belajar dapat mencapai tujuanya, yaitu perubahan, maka setiap individu mempunyai cara tersendiri yang dipilih sesuai dengan dirinya, informasi dari luar dirinya dapat diserap, diolah dan diorganisirkan dengan baik. Sehingga perbedaan gaya belajar yang dipilih individu menunjukkan cara tercepat dan terbaik bagi setiap individu bisa menyerap sebuah informasi dari luar dirinya. Dan pada akhirnya dapat mencapai prestasi belajar yang optimal.

Dengan demikian maka dapat disimpulkan bahwa dengan gaya belajar apapun, jika kita sudah paham betul dengan diri masing-masing individu maka akan dengan mudah untuk menyerap informasi yang ada.

Penelitian ini juga menunjukkan bahwa tidak ada perbedaan nilai rata-rata pencapaian prestasi belajar ekonomi berdasarkan gaya belajar. Dengan nilai rata-rata 73,52 pada siswa SMA Negeri di Kota Tuban memiliki gaya belajar visual, nilai rata-rata UAS 76,47 pada siswa yang memiliki gaya belajar auditorial dan nilai rata-rata 75,48 pada siswa dengan gaya belajar kinestetik. Sehingga dapat disimpulkan bahwa tidak ada gaya belajar siswa tertentu yang mendominasi tingkat prestasi belajar ekonomi.

Hasil penelitian ini sependapat dengan penelitian Tanta (2010), Indarto (2012), dan Englander,dkk (2011) yang menyimpulkan bahwa gaya belajar secara signifikan berpengaruh terhadap prestasi belajar siswa. Hal ini didukung oleh pendapat Bobbi DePotter dan Hernacki (2001) menyebutkan bahwa mengetahui gaya belajar yang berbeda telah membantu para siswa, dengan demikian akan memberikan persepsi yang positif bagi siswa tentang cara mengajaar guru mengajar.

Berdasarkan hasil pengujian hipotesis dan hasil penelitian terdahulu tidak ditemukan hasil penelitian yang bertolak belakang dengan hasil penelitian ini. Hasil penelitian terdahulu semuannya memberikan kesimpulan yang sama yaitu motivasi belajar dan gaya belajar berpengaruh signifikan terhadap prestasi belajar siswa.

\section{KESIMPULAN}

Berdasarkan analisis regresi linier berganda, maka kesimpulan yang dapat diambil adalah sebagai berikut :

1. Peningkatan motivasi belajar berdampak nyata pada peningkatan prestasi belajar, dan besarnya pengaruh motivasi belajar terhadap prestasi belajar adalah sebesar $16 \%$.

2. Peningkatan gaya belajar berdampak nyata pada peningkatan prestasi belajar, dan besarnya pengaruh gaya belajar terhadap prestasi belajar adalah sebesar $8,8 \%$. Gaya be- 
lajar yang dipakai dalam pelajaran ekonomi adalah gaya belajar Visual yaitu sebesar $72,8 \%$.

3. Motivasi belajar dan gaya belajar secara simultan berpengaruh signifikan terhadap prestasi belajar dan besarnya pengaruh motivasi belajar dan gaya belajar terhadap prestasi belajar adalah $28,2 \%$ sedangkan sisanya $71,8 \%$ dipengaruhi oleh faktor-faktor lain selain variabel motivasi belajar dan gaya belajar.

Saran yang dapat diberikan berdasarkan hasil penelitian ini adalah :

1. Siswa disarankan memiliki motivasi dorongan dan kebutuhan belajar yang lebih tinggi sehingga prestasi belajar lebih dapat ditingkatkan.

2. Siswa disarankan untuk lebih memfokuskan gaya belajar visual agar dapat lebih meningkatkan

3. Guru lebih memperhatikan dalam memberikan motivasi dalam belajar siswa agar prsetasi belajar siswa dapat ditingkatkan.

4. Dengan memahami gaya belajar siswa, guru diharapkan mampu merancang media,metode/atau materi pembelajaran dengan gambar, grafik, atau menyesuaiakan dengan materi pelajaran.

\section{DAFTAR RUJUKAN}

A.M,Sardiman. (2007). Interaksi dan Motivasi Belajar Mengajar.Jakarta : PT.Raja Grafindo Persada.

Arini,Sukiati,Kadek,Ni. (2009). "Pengaruh Tingkat Intelegensi dan Motivasi Belajar Terhadap Prestasi Akademik Siswa Kelas II SMA negeri 99 Jakarta".

Bobbi, DePorter, dan Mike Hernacki. (2001).Quantum Learning Membiasakan Belajar Nyaman Dan Menyenangkan.Bandung : Kaifa.

Djamarah, Syaiful Bahri. (2002). Psikologi Belajar. Jakarta:Rineka Cipta.

Dimyati \& Mudjiono. (2006). Belajar dan Pembelajaran. Jakarta: Rineka Cipta.

Fred Englander.(2011). "The role Of Learning Style In Student Achievment In An MBA Economics Course".International journal of Education Research, vol 6. No. 2

Hamzah ,Uno. (2006). Teori Motivasi dan Pengukuran.Jakarta: Bumi Aksara.

Hamdu,Ghullam \& Lisa Agustina. (2011). "Pengaruh Motivasi belajar Siswa Terhadap Prestasi Belajar IPA di Sekolah Dasar”. Jurnal penelitian Pendidikan Vol 12. No. 1

Indarto Danang.(2012). “ Pengaruh Gaya Belajar dan Motivasi Berprestasi siswa Terhadap Prestasi belajar Praktik Instalasi Listrik Di SMK Negeri 2 Yogyakarta". Http: // eprints.UNY.ac.id. 2012

Kertamuda Fatchiah.(2008). "Pengaruh Motivasi Belajar Terhadap Prestasi Belajar". Jurnal Psikologi. Vol.21.

M. Joko Susilo. (2006). Gaya Belajar menjadikan lebih Pintar . Yogyakarta Pinus.

Muhibbin, Syah. (2010). Psikologi Pendidikan dengan Pendekatan Baru. Bandung :Remaja Rosdakary

Mulyono, Adi , \& dkk. (2007). “ Pengaruh Pelatihan Gaya Belajar Terhadap Peningkatan 
Indeks Prestasi Mahasiswa”. Jurnal Keperawatan Soedirman Vol. 1 No. 1

Nana Syaodih Sukmadinata. (2009). Landasan Psikologi Proses Pendidikan. Bandung: PT Remaja Rosdakarya.

Prastiti, Sawitri, \& Pujiningsih. (2009). “Pengaruh Faktor-Faktor Preferensi Gaya Belajar Terhadap Prestasi Belajar Mahasiswa Akuntansi”. Jurnal Ekonomi Bisnis Vol 14. No. 3.

S. Nasution.(2003). Berbagai Pendekatan dalam Proses Belajar dan Mengajar. Jakarta : Bumi Aksara.

Sukirman. (2011). "Peran Bimbingan Guru \& Motivasi Belajar dalam Rangka Meningkatkan Prestasi Belajar Peserta Didik SMA Negeri 1 Metro tahun 2010”. Guidena Vol. 1 No. 1

Sumadi Suryabrata. (2002). Psikologi Pendidikan. Jakarta: PT. Raja GrafindoPersada.

Tanta. (2010). “ Pengaruh Gaya Belajar Terhadap Hasil Belajar Mahasiswa Pada Mata Kuliah Biologi Umum Program Studi Pendidikan Universitas Cendrawasi”. Jurnal Kependidikan Dasar vo. 1 no. 1 